
[in English].

10. IISD's Post-2015 Development Agenda Reporting. Negotiations and Processes, available at: http://enb.iisd.org/post2015.

Стаття надійшла до редакції 13.11.2018 p.

UDC 323.15

\author{
Lysenko Oleksandr \\ Doctor of Historical Sciences, Professor, \\ Honored Scientist of Ukraine, \\ State Prize of Ukraine winner, \\ Head of the Department of the Institute of \\ History NAS of Ukraine \\ ORCID 0000-0002-4003-6433 \\ ukr2ww@ukr.net \\ Tohochynskyi Oleksii \\ Doctor of Pedagogical Sciences, \\ Associate Professor, Rector of the Academy of State \\ Penitentiary service \\ ORCID 0000-0001-9446-8605 \\ oleksii_tgch@ukr.net \\ Pekarchuk Volodymyr \\ Doctor of Historical Sciences, Associate Professor, \\ Professor of the Academy of State \\ Penitentiary service \\ ORCID 0000-0002-7750-1474 \\ vladimirpkrk@i.ua
}

\title{
POLITICAL AND LEGAL TOOLS FOR ENSURING THE CULTURAL RIGHTS OF NATIONAL MINORITIES IN UKRAINE IN 1992-2018: BETWEEN DECLARATIONS AND REALITY
}

The purpose of the article is to characterize the political and legal means of regulating the cultural segment of the functioning of national minorities in Ukraine during the period of independence and to analyze the effectiveness of the legal and regulatory framework in resolving existing problems. Methodological approaches are based on polydisciplinary principles of studying the sphere of touch of ethnonational, legal, political and cultural phenomena. This involves taking into account theoretical developments in each of the scientific disciplines within which the specified range of issues is developed, as well as the application of the newest conceptualcategorical apparatus. Through the integrated use of interdisciplinary approaches, the state's steps to regulate the cultural sphere of activity of ethnic and national minorities in modern Ukraine are traced, shortcomings and perspectives are overcome. Scientific novelty of the research is to systematically analyze the factors that influence the process of adopting political and legal documents that meet modern international standards and could accelerate the resolution of pressing problems in this area. Conclusions. The current internal and foreign political situation in Ukraine hinders the rapid resolution of the problems accumulated over many decades in the political and legal regulation of the cultural segment of ethnic minority activity. The action of destructive internal and external factors artificially limited the ability of the state in this regard. At the same time, there are grounds for claiming that there is no goodwill in the political elites that are responsible for resolving such issues. It is necessary to realize that in a rapidly changing world, regulatory support for ethnic policy must respond promptly to the challenges of time and be updated accordingly. The problem of developing adequate tools for the legal provision of cultural rights of ethnonational minorities, as well as the prevention of crisis situations, remains a pressing issue. In order to achieve effective steps in this direction, the state must properly organize their financial and material support.

Key words: Ukraine; national minorities;state ethnopolitics; language and education policy; instruments of protection of cultural rights; legislative acts; state bodies.

Лисенко Олександр Євгенович, доктор історичних наук, профресор, заслужений діяч науки і техніки України, лауреат Державної премії України, завідувач відділу Інституту історії НАН України; Тогочинський Олексій Михайлович, доктор педагогічних наук, доцент, ректор Академії Державної пенітенціарної служби; Пекарчук Володимир Михайлович, доктор історичних наук, доцент, професор Академії Державної пенітенціарної служби

Політико-правові інструменти забезпечення культурних прав національних меншин в Україні у 1992-2018 роки: між деклараціями та реальністю

Мета дослідження полягає у характеристиці політико-правових засобів регулювання культурного сегменту функціонування національних меншин в Україні у період незалежності, аналізі ефективності нормативно-правової бази у врегулюванні існуючих проблем. Методологічні підходи ґрунтуються на полідисциплінарних засадах вивчення сфери дотику етнонаціональних, правових, політичних, культурних явищ. Це передбачає врахування теоретичних напрацювань у кожній з наукових дисциплін, у межах яких розробляється вказане коло питань, а також застосування новітнього понятійно-категоріального апарату. За допомогою комплексного використання міждисциплінарних підходів простежуються кроки держави з урегулювання культурної сфери діяльності етнічних і національних меншин в сучасній Україні, з'ясовуються недоліки та перспективи їх подолання. Наукова новизна дослідження полягає у системному аналізі чинників, що впливають на процес ухвалення політикоправових документів, які відповідали б сучасним міжнародним стандартам і могли б прискорити розв'язання нагальних проблем у вказаній сфері. Висновки. Сучасна внутрішньо- і зовнішньополітична ситуація в Україні перешкоджає швидкому вирішенню

(C) Lysenko O., 2019

(C) Tohochynskyi O., 2019

(C) Pekarchuk V., 2019 
проблем, що накопичувалися впродовж багатьох десятиліть у політико-правовому регулюванні культурного сегменту діяльності етноменшин. Дія деструктивних внутрішніх і зовнішніх чинників штучно обмежувала можливості держави в цьому плані. Водночас існують підстави для констатації відсутності належної волі у політичних елітах, на які покладається вирішення таких питань. Необхідне усвідомлення того, що у світі, який швидко змінюється, нормативно-правовий супровід етнополітики має оперативно реагувати на виклики часу й оновлюватися відповідним чином. Залишається актуальною проблема вироблення адекватного інструментарію правового забезпечення культурних прав етно-національних меншин, а також попередження кризових ситуацій. Аби домогтися ефективності кроків у цьому напрямі, держава має належним чином організувати їх фінансово-матеріальну підтримку.

Ключові слова: Україна; національні меншини; етнополітика держави; мовна й освітня політика; інструменти захисту культурних прав; законодавчі акти; державні органи.

Лысенко Александр Евгеньевич, доктор исторических наук, профессор, заслуженный деятель науки и техники Украины, лауреат Государственной премии Украины, заведующий отделом Института истории НАН Украины; Тогочинский Алексей Михайлович, доктор педагогических наук, доцент, ректор Академии Государственной пенитенциарной службы; Пекарчук Владимир Михайлович, доктор исторических наук, доцент, профессор Академии Государственной пенитенциарной службы

Политико-правовые инструменты обеспечения культурных прав национальных меньшинств в Украине в 1992-2018 годах: между декларациями и реальностью

Цель статьи заключается в характеристике политико-правовых средств регулирования культурного сегмента фрункционирования национальных меньшинств в Украине в период независимости, анализе эффективности нормативно-правовой базы для урегулирования существующих проблем. Методологические подходы базируются на полидисциплинарной основе изучения сферы соприкосновения этно-национальных, правовых, политических, культурных явлений. Это предполагает учет теоретических наработок в каждой из дисциплин, в рамках которых разрабатывается указанный круг вопросов, а также применение новейшего понятийно-категориального аппарата. С помощью комплексного использования междисциплинарных подходов прослеживаются шаги государства по урегулированию культурной сферы деятельности этнических и национальных меньшинств в современной Украине, выясняются недостатки и перспективы их преодоления. Научная новизна исследования заключается в системном анализе факторов, влияющих на процесс принятия политико-правовых документов, которые отвечали бы современным международным стандартам и могли бы ускорить решение насущных проблем в указанной сфере. Выводы. Современная внутри- и внешнеполитическая ситуация в Украине препятствует быстрому решению проблем, которые накапливались в течение многих десятилетий в политико-правовом регулировании культурного сегмента деятельности этнических меньшинств. Действие деструктивных внутренних и внешних факторов искусственно ограничивало возможности государства в этом плане. В то же время есть основания для констатации отсутствия надлежащей воли в политических элитах, на которые возлагается решение таких вопросов. Необходимо осознание того, что в быстро меняющемся мире, нормативноправовое сопровождение этнополитики должно оперативно реагировать на вызовы времени и обновляться соответствующим образом. Остается актуальной проблема выработки адекватного инструментария правового обеспечения культурных прав этно-национальных меньшинств, а также предупреждения кризисных ситуаций. Чтобы добиться эффеективности шагов в этом направлении, государство должно надлежащим образом организовать их фринансово-материальную поддержку.

Ключевые слова: Украина; национальные меньшинства; этнополитика государства; языковая и образовательная политика; инструменты защиты культурных прав; законодательные акты; государственные органы.

The relevance of research topic. The social relevance of the topic of research is determined by the current internal and external threats and challenges, and scientific - the need for a comprehensive analysis of the state of political and legal regulation of the cultural rights of ethnic and national minorities, which are recommended for state bodies involved in this sphere. The complex domestic political processes in Ukraine in recent decades, the hybrid war of the Russian Federation against our country, large-scale migration flows in different regions of the world, which have become a global problem, transform the ethnopolitical sphere into one of the actual areas marked by challenges for the state-building processes in our country. One of the areas of state policy is to address issues related to the livelihoods of various ethnic communities within the country. O. Maiboroda defines ethnopolitics as a sphere of social life in poly-national states, which includes the political relations of a state-nation ("the nation-state") [1, 488].

Successful implementation of the course of the state on the development of civil society is possible provided political and legal support, which should ensure the cultural rights of ethnonational minorities in Ukraine. Implementation of practical steps in this direction should be promoted by higher authorities and administrations, special executive structures of the corresponding profile, reliable instruments of regulation of this sphere. Delaying of solving a complex of problems that require carefully selected steps provokes latent tension in society and undermines the international image of Ukraine.

Analysis of research and publications. Theoretical and methodological work of foreign and domestic sociologists, political scientists, psychologists, and ethnologists contributed to a deeper understanding of the nature of ethnopolitics, the formation of a scientific thesaurus, as well as conceptual constructions, in which the ethnopolitical processes of the past and the present fit. These include G. van Amersfoort, S. Wegli, L.Wirth, M. Harris, V. Bochkovsky, F. Capotorti, S. Yuriev, A. Antonyuk, V. Yevtukh, J. Kotlyar, O. Mayboro$\mathrm{da}$, and others.

The various aspects of the political and legal provision of cultural rights of national minorities are devoted to the publication of N. Golobor, N. Papish, O. Fedul, V. Lemanta, A. Leshmak, A. Popok, Yu. Rymarenko, M. Lazarovych, O. Lytvynenko, V. Chumak, M. Almasha, A. Shaikhatdinova, K. Vitman, L. Ryaboshapko, V. Borodinov and others. The publications of these specialists cover a wide range of issues related to the formation of a legal field in which public institutions representing the ethnic and national communities of Ukraine.

The purpose of the research is to provide a comprehensive description of the peculiarities of the political and legal regulation of the sphere of cultural activity of ethnonational minorities in Ukraine, the peculiarities of the process of optimizing relations between them and the state. 
The methodological basis of intelligence is a set of modern theoretical and conceptual approaches to the study of complex ethnopolitical problems. The poly-disciplinary nature of the phenomena under study involves the use of methods of various sciences, in particular, political science, history, ethnology, philosophy, and others, as well as the corresponding theoretical apparatus.

Presenting the main material. The normative legal basis for any steps of the state in the ethnopolitical sphere, as well as the social life of all ethnic communities, is the Constitution of Ukraine and the corresponding laws and legal acts of the higher authorities and administration. In Art. 24 of the Basic Law emphasizes equal constitutional rights and freedoms and equality of all citizens before the law, absence of "privileges or restrictions on grounds of race, color of the skin, political, religious and other beliefs, sex, ethnic and social origin, property status, place of residence, linguistic or other features "[2].

By adopting the Law of Ukraine "On National Minorities in Ukraine" on June 25, 1992, the Verkhovna Rada of Ukraine issued "on the vital interests of the Ukrainian nation and all nationalities in the development of an independent democratic state, recognizing the indissolubility of human rights and the rights of nationalities, striving to implement the Declaration of the Rights of Nationalities of Ukraine, adhering to international obligations regarding national minorities ". In Art. 6 of the Law provides a guarantee to all national minorities of the right to national and cultural autonomy: "the use and training in their native language or the study of their native language in public educational institutions or through national cultural societies, the development of national cultural traditions, the use of national symbols, the celebration of national holidays, the practice of their religion, meeting the needs of literature, the arts, the media, the creation of national cultural and educational institutions, and any other activities that e contradicts the legislation in force "[3].

Matters related to the situation of national minorities in Ukraine do not belong exceptionally to the internal affairs of Ukraine. As a member of many international organizations and counteragent of interstate agreements, Ukraine has undertaken a number of commitments, among other things, in the ethnopolitical sphere.

On December 18, 1992, the UN General Assembly adopted a "Declaration on the Rights of Persons Belonging to National or Ethnic, Religious and Linguistic Minorities." In clause 3 of Art. 4 of this document states: "States shall take appropriate measures to ensure, wherever possible, that persons belonging to minorities have the appropriate opportunities to study their mother tongue or their mother tongue [4].

December 9, 1997, by Law No. 703/97 - VR Ukraine ratified the Framework Convention for the Protection of National Minorities. In Art. 14 of this document stipulates that "a place in the ownership of which persons belonging to national minorities traditionally live or they are considered significant parts of the population, if necessary, trying to provide the opportunity and scope of their rights belonging to these minorities, appropriate conditions for language teaching by the relevant minorities, or for learning that language. "However, this item should be without schools for the study of official languages or teaching in this language [5].

Even in the time of the establishment of the Organization for Security and Cooperation in Europe (OSCE) in 1975, the following principles of policy aimed at the harmonization of interethnic relations were fixed in its documents: issues concerning national minorities are not merely an internal affair of the respective states, but, consequently, can be the subject of legitimate interference by international organizations [ 6 , 39].

In the directive of the Council of the European Union of 29th of June, 2000 on the implementation of the principle of equal treatment of persons irrespective of racial or ethnic origin, the approaches adopted by the European community in this matter [7] are established.

The provisions, regulations, and recommendations of these and other documents make Ukrainian politicians and state leaders take into account the international legal field, which addresses the problems of ethnopolitics. At the same time, it creates the grounds for relying on the mirroring effects of other partners or countries that have to contact with conflict issues.

At one time, the Russian Federation used claims to Ukraine about the oppression of our fellow citizens on the language sign for pressure on her, as well as the formation of a negative image of Ukraine in the world. Soon the world community was convinced that it was part of the hybrid war of the Russian Federation against Ukraine.

On $2^{\text {nd }}$ of October, 2018, the expert council of the Ministry of Culture of Ukraine on Ethnopolitics and the Council of Ethnic and National Organizations held a joint meeting to discuss the draft Law of Ukraine "On the Concept of the State Ethnic and Ethnic Policy of Ukraine". The preparation of this document relied on a permanent advisory body under the Ministry of Culture of Ukraine - the Expert Council on Ethnic Policy. The draft law was prepared for the implementation of sub-item 2 of item 112 of the Plan of measures for the implementation of the national strategy on human rights for the period up to 2020, approved by the Cabinet of Ministers dated November 23, 2015, No. 1393-p.

According to the words of the director of the Department for Religious Affairs and Nationalities of the Ministry of Culture of Ukraine A. Yurash, the development of the Concept aims to determine the content and orientation of the state ethnonational policy, to introduce in the legislation a unified conceptual apparatus, common principles, goals, directions and mechanisms of state policy in the ethnopolitical sphere. The main provisions of the Concept are supposed to be the basis for improving the existing and the formation of new legislation in the field of interethnic relations. 
The participants of the meeting discussed the document, and representatives of public organizations of national communities criticized some of its wording and made appropriate proposals, approving it in general [8].

Since the Concept has to become a legislative act that defines the content and direction of the state ethnopolitics, its characterization must be in priority. The document consists of 8 Chapters. The first of them "General Provisions" states that "due to the peculiarities of the historical development of Ukraine, in particular its desubjectivization in world history, the marginalization of the Ukrainian language and the languages of other ethnic communities, ethnocultural assimilation of Ukrainians and representatives of other peoples in Ukraine, an ethnopolitical situation was formed, in which none of the ethnic communities were able to fully realize their rights related to ethnic origin. Under such conditions, not only national minorities but also the ethnic majority - Ukrainians, whose identity in a number of regions has been largely lost, need protection. "

The reason for this is "the need for consistent state policy in the field of interethnic relations, meeting the needs and observance of the rights of representatives of all ethnic communities of Ukraine, as well as the need for differentiation of mechanisms and methods for the implementation of state ethnonational policies by the authorities."

From the methodological point of view, it is extremely important to define the basic concepts (Chapter 2), which must unify the thesaurus of normative legal acts and ensure their consistent interpretation. Here are definitions of terms such as "state ethnonational policy of Ukraine" (state ethnopolitics of Ukraine)", "nationality "(ethnic belonging)," Ethnic group "," Ukrainian nation "("Ukrainian ethnic nation")," Ukrainian people " ("Ukrainian political nation"), "national minority", "national-cultural autonomy", "minority minority", "indigenous people of Ukraine", "special measures of support".

Chapter 3 formulates the principles of state ethnonational policy, covering:

- inviolability of territorial integrity;

- rule of Law;

- consideration of factors, influencing the state of interethnic relations (the formation of national legislation that guarantees the development of ethnic identity, the preservation of cultural and linguistic identity by all ethnic communities;

- overcoming the consequences of the policy of assimilation and rationalization of the population of Ukraine as a result of the totalitarian policy of the USSR;

- development of the latest communications and urbanization and globalization processes requiring new approaches to solving problems related to the preservation and development of ethnic identity;

- institutional weakness of state institutions, responsible for the formation of state and ethnonational policy, lack of strategy and weak organizational and functional support for the implementation of state ethnonational policy through the system of executive authorities at both central and regional levels;

- prevention of ethnic conflicts; counteracting any manifestations of xenophobia, incitement to racial, national, ethnic, religious hatred;

integration of ethnic communities into Ukrainian society through the formation of a common informational and cultural space and historical memory, national events, etc.;

- self-identification - a guarantee of the rights of a person to self-determination of ethnic identity or its absence;

- inclusiveness - the creation of conditions for the involvement of ethnic communities of Ukraine in the discussion and preparation of legislative initiatives;

- equality before the law;

- symmetry and reciprocity in inter-state contacts and agreements aimed at ensuring the preservation of language and cultural identity of national minorities;

- proportional efforts - the provision of resources, mechanisms and methods of state policy implementation by the state depending on the specifics and ethnic composition of the population of the regions.

The purpose and tasks of the state ethnonational policy of Ukraine are presented in Chapter 4. Its purpose is defined "creation of conditions for the consolidation and development of the Ukrainian nation, its historical consciousness, traditions and culture, as well as for the development of the ethnic, cultural, linguistic and religious identity of indigenous peoples and national minorities, the integration of all ethnic communities into the Ukrainian political nation (Ukrainian people) on the basis of the recognition of human rights and freedoms, the foundation for the effective updating of legislation in the field of interethnic relations".

The main tasks include "promoting the development of equal relations between representatives of the Ukrainian ethnic nation, indigenous peoples and national minorities, and other ethnic communities living in Ukraine; forming an atmosphere of interethnic tolerance and harmony in Ukrainian society; ensuring equal opportunities in the economic, social, political and cultural spheres of society for all its citizens, regardless of race, gender, ethnic and social status, property status, place of residence, political, religious beliefs, linguistic and other features."

The directions of realization of the state ethnonational policy of Ukraine (Chapter 5) are described in four areas: political and legal, cultural and humanitarian information, foreign policy.

Since the article deals with the political and legal aspects of the problem, we note that the authors of the "Concept" managed to clearly formulate priorities, in particular: the development and improvement of the 
legislative framework aimed at regulating ethnonational relations on the basis of the implementation of international law, taking into account progressive domestic and foreign experience in the ethnopolitical sphere; diversification of state policy in accordance with the conditions of separate regions; development of scientifically grounded approaches to solving problems of ethnonational relations, first of all, those concerning problem integration and consolidation of Ukrainian society and others.

In the cultural and humanitarian sphere there are such conditions as involvement of ethnic communities in the development and implementation of state programs, action plans, etc., aimed at developing their cultural identity; implementation of the state language policy based on the norms of national and international law, ensuring the comprehensive development and functioning of Ukrainian language as a state in all spheres of social life throughout the territory of Ukraine; formation of a common historical memory of the Ukrainian political nation; dissemination of values of interethnic accord and preventive actions in order to prevent xenophobia, incitement to national, racial and religious hatred; realization of the right of national $\mathrm{mi}$ norities to national-cultural autonomy.

The "Concept" provides mechanisms for implementing the tasks of ethnonational policy (Chapter 6). It is fundamentally important here to fix the provision on the authorized central body of state power and local executive bodies, which should be based on the expert-analytical environment, advisory civil councils and other civil society institutions.

In this part of the document, the definition of "special measures of support" of indigenous and national minorities, including synchronization of the legal field (international and domestic), implementation of the relevant state programs, strategies or action plans, regular monitoring of ethnonational programs in Ukraine in order to identify problematic issues and rapid response, the involvement of foreign partners and international organizations in solving complex issues in the field of ethnic policy caused by armed aggression of the Russian Federation against Ukraine and occupation of its territory.

The document indicates how to finance practical activities in the ethnopolitical sphere and the expected results.

At the same time with all the positive features of the document (in its accessible and, possibly, not the final form) has some formal-stylistic and structural disadvantages. In particular, it seems more logical when the purpose and tasks convey the presentation of principles because the latter serve as a means of achieving the goal and instrumentalization of ethnopolitics. More specifically, the mechanism for implementing the course of the state in this area, in particular, in parts related to the algorithm of interaction between authorities and public institutions, as well as interstate contacts (in order to achieve parity in updating and solving existing problems, development of arbitration mechanisms, etc.), was to be written out. It is worthwhile in a specific way, at least, to indicate legal sanctions (administrative, criminal) for incitement of interethnic hostility by politicians, officials, non-state institutions and individual citizens.

Welcoming the preparation and the appearance of such a document, surprise could be the fact only that it took almost three decades since the emergence of a sovereign Ukrainian state.

The cultural sphere belongs to those zones of activity of ethnic communities, in which the most distinctive traditions, customs, artistic forms of self-expression and self-identification appear to be the most distinctive. In general, favorable conditions for the realization of cultural rights of national minorities have been created in Ukraine.

Till the beginning of 2016, there were 778 national-cultural societies operating in Ukraine, 28 of which have an all-Ukrainian status [9, 18]. The following cultural and artistic events such as the All-Ukrainian Festival "We are Ukrainian", the Forum of National Cultures "We all are your children, Ukraine!", International Roman Festival "Amal", regional cultural events with the participation of Romanian, Polish, Greek, Crimean Tatar, Armenian, Moldavian, Korean artistic groups and many others were the most noticeable phenomena of social life.

A slightly different situation is observed in the language sphere. In order to resolve the entire complex of issues related to the status of the state language and the functioning of the languages of national minorities, the Verkhovna Rada of Ukraine adopted the Law "On the Principles of State Language Policy". However, some provisions of this act contradict the Basic Law of the country, since they leave the local authorities the right to recognize the regional languages of certain ethnic communities. Instead, solving such issues is the exclusive prerogative of higher authorities. In addition, this Law, in fact, discriminates against the languages of those minorities, who did not fall into the recognized legal instrument of the 18 languages that may qualify for the status of regional or minority languages. The appeal of this Law by a group of national deputies in the Constitutional Court in 2014 has transferred discussions to a protracted phase.

The language issue is actively used by certain political forces, some political circles of the nearby states, forming on its speculations its political technologies and strategic scenarios, which harms the image of Ukraine in the world.

In order to resolve the linguistic problems in our country an appropriate legal basis has been formed, the starting point of which is the Constitution of Ukraine. In the Basic Law, the status of the state is established in Ukrainian (Art. 10), and "to citizens, who belong to national minorities, in accordance with the law, are guaranteed the right to study their mother tongue in state and communal educational institutions or through national cultural societies" (Article 53) [2]. 
At the end of 1997, the highest legislative body of the state ratified the Framework Convention for the Protection of National Minorities. The document states among others the following provision: "The Parties shall endeavor to ensure, whenever it's possible, the conditions, allowing the use of the language of the national minority in communicating these persons among themselves and with the administrative authorities," as well as "guaranteeing every person belonging to a national minority, the right to be immediately informed in a language understandable to her ... "[10,65].

The framework of the Framework Convention was based on specific conditions and opportunities in each country.

A bit more difficulties arise in the interpretation of the European Charter for Regional or Minority Languages (November 5, 1992), to which Ukraine joined in May 1996. During the preparation for ratification of the document, a number of issues related to the adaptation to domestic realities. In particular, Russian, Yiddish and Hebrew, Belorussian, Polish, Crimean Tatar, Hungarian, Romanian, Moldavian, Bulgarian, Greek, German, Slovak, and Gagauz languages were identified to the languages of national minorities.

Basically, by adding to the charter, Ukrainian legislators implemented a norm according to which, in cases where the number of ethnic groups within the territorial administrative unit reached $20 \%$, their language acquired official status here. The law on the ratification of the Charter did not establish exactly whether the speakers of the language or those who identified themselves as a minority member on a purely ethnic basis [11].

The imperfection of the law on the ratification of the Charter (December 1999) became a reason for a lawsuit to the Constitutional Court of Ukraine, which declared it invalid. Taking into account the comments, the Charter was ratified by the Verkhovna Rada of Ukraine in May 2003.

Together with the laws of Ukraine "On Languages", "On Education", "On Extracurricular Education", "On General Secondary Education", "On printed mass media (press) in Ukraine", "On information" and other law on ratification of European the charter has created the prerequisites for the fruitful cooperation of state authorities and public organizations of national minorities in the direction of harmonization of the linguistic sphere.

But if in case of Russian language a long-term strategy of the forces oriented toward the Russian Federation (while they did not contest the authorities' actions regarding the Russian language, but sought to give it the status of a second state), then the Hungarian "linguistic question" had slightly different roots. As you know, in violation of the legislation of Ukraine, the Hungarian consular services issued Hungarian passports to the inhabitants of Transcarpathia. Budapest has for a long time accused Ukraine of violating the rights of the 130,000-strong Hungarian minority. Without going into the detailed presentation of the vicissitudes, in this case, we restrict ourselves to one remark. The Ukrainian state must adhere to a clear, reasoned and, at the same time, firm stand based on legally established norms that are in line with international standards and practices. The adoption of the law on education at the end of 2017 demonstrated exactly these approaches, after which the Hungarian side went to certain acts, in particular, stopped issuing its passports to Ukrainian citizens and began organizing courses for the Ukrainian language for the Hungarian people of Transcarpathia.

Significant difficulties on the way to resolving the problems arising in the sphere of ensuring cultural rights of national minorities arise from the lack of a specialized state body, although its creation was foreseen by the Law "On National Minorities in Ukraine". It should not have become the Ministry for Nationalities of Ukraine. It was planned to form an advisory structure - the Council of Representatives of Public Associations of National Minorities of Ukraine. However, the leadership of the state confined itself to passing the powers of the State Committee on Nationalities and Religions abolished in 2010 and the establishment of the Department of National Minorities of Ukraine and the Ukrainian Diaspora and the language policy sector within the Department for Religious and National Affairs, which is responsible for resolving these issues.

The institutional transformation has had a detrimental effect on the political and legal provision of cultural rights of national minorities. The Commissioner of the Verkhovna Rada of Ukraine on Human Rights in his annual report "On the Status of Observance and Protection of Human Rights and Freedoms in Ukraine" in 2011 pointed out that, as a result of the liquidation of the specialized body, "the role of public administration in the field of ethnonational policy was actually destroyed" which hampered the preparation of such urgent bills as "On the Concept of the State Ethnic and Ethnic Policy of Ukraine", "On Amendments to the Law of Ukraine", "On Ratification of the European Charter for Regional or Minority Languages" "On renewal of the rights of persons deported on national grounds". During the parliamentary hearings on this issue, recommendations were made that emphasized the need to establish a State Service for Nationalities and Religions.

Conclusions. An analysis of the current ethnopolitical situation in Ukraine provides grounds for the emergence of problems that require well-considered decisions of the authorities and all interested parties:

- Getting a balance between universal and differentiated approaches to solving problems that exist in the field of ethnopolitics, different regions of Ukraine, taking into account specifics.

- Due to the creation of Local Orthodox Church in Ukraine, certain political forces deliberately positioning the UOC (MP) as a marker of Russian self-identification. At the same time intentionally (or due to lack of knowledge) the fact that for many believers and clerics of this confession, belonging to it is deter- 
mined not by ethnic, but by esoteric religious motivations is ignored. The rigid consolidation of such binary scheme in political and social practice forms the preconditions for internal discomfort, a sense of inferiority and discrimination against citizens with another identical model: "Ukrainian - a believer of the UOC (MP)." Any legitimization of such approaches by definition will program antagonisms and create artificial obstacles on the way to the consolidation of the Ukrainian political nation. The leadership of the state must understand not only the threats and challenges that are catalyzed by religious instruments of influence, but also the complexity and different interpretation of the "canonical" problems of each of the confessions operating in Ukraine, seeking their convergence, and, in the long run, uniting into a single church organism, and not resort to pressure in any form.

- The need to enable the foreign policy measures regarding the protection of the cultural rights of the Ukrainian community living in one or another country, as well as citizens who are temporarily abroad (first of all, migrant workers).

-There is an urgent need to find adequate tools for spreading the state language in all spheres of public life, wholly excluding coercion in any form as a means of achieving the goal. The politician and the general public must understand the harm caused by democratic resolution of the linguistic issue, both its ignoring and artificial inspirations, which caused conflict-based situations on this ground and anti-Ukrainian mood in some regions.

- The elaboration of a strategy and concrete solutions in the ethnopolitical sphere should be based on the awareness that the zone of potential antagonisms is international relationships, and, more often, contacts through the "state (other states)" ethnic minorities/communities.

- In the last case, there are two political lines: internal and external. At the same time, under the current circumstances (aggression from Russia and the occupation of several large regions of Ukraine, the presence of complex issues in relations with several western neighbors of Ukraine), the foreign policy vector needs special attention, not only diplomatic measures, but also other instruments for their solution.

- There is an urgent need for a deep examination and, if necessary, practical application of the experience of bilateral contacts of the states that have signed agreements to regulate issues related to the vital functions of national minorities (eg. Germany and Poland, Lithuania and Poland, Ukraine and Poland).

- In a similar way, a systematic study of the place and role of public associations of national minorities in the socio-political and socio-cultural processes of other countries is needed in order to use the best examples of their cooperation with the authorities in the state construction in Ukraine.

- In a rapidly changing world, legal and regulatory support for ethnic policy should be quickly regulated by the challenges of time and updated accordingly. Unfortunately, the governing bodies have not yet reached the current level of management in this area, and bureaucratic inertia prevents timely response to emerging issues. This is particularly evident in both the legislative process and the level of improvement of the mechanisms for implementing the state strategy.

- Not the least reason for the disadvantages is the lack of financial and material support for practical steps in this segment, which places Ukraine at a disadvantage compared with other democratic states and prevents the implementation of promising plans.

\section{תimepamypa}

1. Мала енциклопедія етнодержавознавства / НАН України; Інститут держави і права ім. В. М. Корецького; редкол.: Ю. І. Римаренко (відп. ред.) та ін. Київ: Генеза: Довіра, 1996. 942 с.

2. Конституція України: прийнята на п'ятій сесії Верховної Ради України 28 червня 1996 року. К/: Юрінком, 1996. 80 с.

3. Про національні меншини в Україні: Закон України від 25.06.1992 р. № 2494-ХІІ. Відомості Верховної Ради України. 1992. № 36. Ст. 529 .

4. Декларація про права осіб, що належать до національних або етнічних, релігійних і мовних меншин: прийнято резолюцією 47/135 Гнеральної Асамблеї ОOH від 18 грудня 1992 року / Верховна Рада України. URL: https://zakon.rada.gov.ua/laws/show/995_318.

5. Рамкова конвенція про захист національних меншин (1995): ратифіковано Законом України від 9 грудня 1997 р. № 703/97-ВР. Відомості Верховної Ради України. 1998. № 1. Ст. 56

6. Мицик В. В. Права національних меншин у міжнародному праві: монографія. К/: Київський університет, 2004. 287 с.

7. Про імплементацію принципу рівноправності осіб незалежно від расової або етнічної приналежності: Директива Ради Європейського Союзу 2000/43/ЄС від 29 червня 2000 року. URL: http://online.budstandart.com/ru/ catalog/docpage.html?id_doc=67416.

8. Експертна рада Міністерства культури України з питань етнополітики та Рада етнонаціональних організацій України обговорили проект концепції державної етнонаціональної політики України (02.10.2018). URL: http://mincult.kmu.gov.ua/control/publish/article?art_id=245420151.

9. Федунь О. В., Папіш Н. І. Політико-правові аспекти захисту прав національних меншин в Україні. Грані. 2016. № 2 (130) лютий. С. 15-21.

10. Мовна політика та мовна ситуація в Україні: аналіз і рекомендації / за ред. Юліане Бестерс-Дільґер. Київ: КиєвоМогилянська академія, 2008. 364 с.

11. Про ратифрікацію Європейської хартії регіональних мов або мов меншин: Закон України від 15.05.2003 р. № 802-IV. Відомості Верховної Ради України. 2003. № 30. Ст. 259. URL: https://zakon.rada.gov.ua/laws/show/802-15.

\section{References}

1. Rymarenko Yu. (1996). Little encyclopedia of ethnostate studies. Kyiv: Genesis: Dovira. [in Ukrainian]. Ukrainian].

2. Constitution of Ukraine: adopted at the fifth session of Verkhovna Rada of Ukraine on June 28, 1996. Kyiv: Yurinkom. [in 
3. On National Minorities in Ukraine: Law of Ukraine dated 25.06.1992 No. 2494-XII. Bulletin of Verkhovna Rada of Ukraine. 1992. No. 36. Art. 529.

4. Declaration on the rights of persons belonging to national or ethnic, religious and linguistic minorities: adopted by resolution 47/135 of General Assembly of the UNO from December 18, 1992, Verkhovna Rada of Ukraine. URL: https://zakon.rada.gov.ua/laws/show/995_318.

5. Framework Convention on the protection of national minorities (1995): ratified by the Law of Ukraine from December 9 , 1997, No. 703/97-VR. Bulletin of Verkhovna Rada of Ukraine. 1998. No. 1. Art. 56.

6. Mytsyk V.V. (2004). Rights of national minorities in international law. Monograph. Kyiv: Kyiv University. [in Ukrainian].

7. On the implementation of the principle of equality of persons regardless of racial or ethnic origin: Directive of the Council of the European Union 2000/43 / EU from June 29, 2000. URL: http://online.budstandart.com/ catalog / doc-page.html? Id_doc $=67416$.

8. The Expert Council of the Ministry of the culture of Ukraine on ethnic-policy and the Council of Ukrainian ethnonational organizations discussed the draft concept of the State Ethno-national Policy of Ukraine (10.2.2018). URL: http://mincult.kmu.gov.ua/control/publish/article?art_id=245420151.

9. Fedun O.V., Papish N.I. (2016). Political and legal aspects of protection of the rights of national minorities in Ukraine. Fringes. No. 2 (130) February. Pp. 15-21.

10. Julianne Bester-Dilger. (2008). Language policy and language situation in Ukraine: analysis and recommendations. Kyiv: Kyiv-Mohyla Academy. [in Ukrainian].

11. On ratification of the European Charter for Regional or Minority Languages: Law of Ukraine dated May 15, 2003, No. 802IV. Bulletin of Verkhovna Rada of Ukraine. 2003. No. 30. Art. 259. URL: https://zakon.rada.gov.ua/laws/show/802-15.

Стаття надійшла до редакції 25.09.2018 p.

УДК 316.7

\author{
Ломачинська Ірина Миколаївна \\ доктор фрілософських наук, професор, \\ професор кафедри фрілософії \\ Київського університету імені Бориса Грінченка \\ lomachinskairina@ukr.net \\ ORCID 0000-0003-2537-6322 \\ Бондар Тетяна Іванівна \\ кандидат філософських наук, доцент, \\ доцент кафедри фрілософії \\ Київського університету імені Бориса Грінченка \\ t.bondar@kubg.edu.ua \\ ORCID 0000-0001-6796-0063
}

\title{
СВІТОГЛЯДНА СУТНІСТЬ ФЕНОМЕНУ ІНФОРМАЦІЙНОЇ КУЛЬТУРИ В КОНТЕКСТІ ГЛОБАЛІЗАЦІЙНИХ ВИКЛИКІВ СУЧАСНОСТІ
} Метою дослідження є аналіз світоглядних засад феномену інформаційної культури як визначального чинника функці-
онування складних інформаційних систем у сучасну глобалізаційну епоху. Методологія дослідження ґрунтується на діалектич-
ному взаємозв'язку таких методів: порівняльно-історичного - у визначенні генези інформаційної культури; системно-
структурного підходу - задля осмислення інфоормаційної культури як визначального чинника функціонування складної інфрорма-
ційної системи у ії структурних взаємозв'язках; синергетичного підходу - у процесі аналізу соціально-культурної зумовленості
функціонування складних інформаційних систем. Наукова новизна полягає в аналізі феномену інформаційної культури крізь
призму функціонування різних видів складних інформаційних систем. Висновки. У статті доведено необхідність усвідомлення
інформаційної культури як визначального чинника ффункціонування складних інформаційних систем. Інформаційна культура
визначає міру досконалості суспільства в його здатності ефективно використовувати інформаційні ресурси та засоби інфрор-
маційних комунікацій і долати інформаційні загрози.

Ключові слова: інформаційна культура; інфрормаційна система; інфрормаційне суспільство; інформаційні ресурси; соціально-комунікаційні інститути; інформаційні потреби; інформаційна загроза; інформаційна безпека.

Ломачинская Ирина Николаевна, доктор фрилософских наук, профессор Киевского университета имени Бориса Гринченко; Бондарь Татьяна Ивановна, кандидат философрских наук, доцент Киевского университета имени Бориса Гринченко современности

Мировоззренческая сущность феномена информационной культуры в контексте глобализационных вызовов

Целью исследования является анализ мировоззренческих основ феномена информационной культуры как определяющего фактора функционирования сложных информационных систем в современную глобализационную эпоху. Методология исследования основывается на диалектической взаимосвязи следующих методов: сравнительно-исторического - в определении генезиса информационной культуры; системно-структурного подхода - для осмысления информационной культуры как определяющего фактора функционирования сложной информационной системы в ее структурных взаимосвязях; синергетического подхода - в процессе анализа социально-культурной обусловленности функционирования сложных информационных систем. Научная новизна заключается в анализе феномена информационной культуры сквозь призму функционирования различных видов сложных информационных систем. Выводы. В статье доказана необходимость осознания информационной культуры как определяющего фактора функционирования сложных информационных систем. Информационная культура определяет степень совершенства общества в его способности эффрективно использовать информационные ресурсы и средства информационных коммуникаций, а также преодолевать информационные угрозы.

() Ломачинська І. М., 2019

(C) Бондар Т. І., 2019 